İşletme Akademisi Dergisi
2020, $1(3): 275-293$
DOI:10.26677/TR 2010.2020 .546
Dergi web sayfass: www.sakder.org

Araștırma Makalesi

\title{
COVID-19 Sağlık Krizinde Raylı Toplu TaşımadakiMaliyet Sorununa Bölgesel Tarife Önerisi: Eskişehir Uygulaması
}

\author{
Prof.Dr. Vedat EKERGİL \\ Anadolu Üniversitesi, Açıköğretim Fakültesi, Eskişehir \\ vekergil@anadolu.edu.tr, https://orcid.org/0000-0002-6790-8529
}

\section{Erkan KODALAK}

SMMM, Muhasebe Bilim Uzmanı, İstanbul

erkankodalak@gmail.com, https://orcid.org/0000-0001-5253-1194

Öz

Türkiye'de COVID-19'un 11 Mart 2020'den itibaren gündeme yerleşmesiyle; "sosyal mesafe", "okullarda uzaktan öğretime geçilmesi”, "20 yaş altı ve 65 yaş üstü sokağa çıkma kısıtlaması", "toplu taşımada ayakta yolcu uygulamasının kaldırılması ve oturan yolcu sayısının azaltılması" gibi birçok önlem toplu taşımacılığa yeni bir anlayış getirmiştir. Normalleşme süreciyle birlikte tüm önlemler kaldırılmış olsa da, virüs varlığını yaz dönemi boyunca hissettirmeye devam ettirmiştir. Dolayısıyla ulaşım sistemini yeniden gözden geçirerek; daha esnek, verimli ve kesintisiz bir yapıya doğru taşımak gerekmektedir. Bu makalede COVID-19'un ortaya çıkardığ 1 finansal ve ekonomik krizi "sağlık krizi" olarak isimlendirilmiştir. Bu çalışmanın amacı; sağlık krizi ile birlikte toplu taşımada ortaya çıkan maliyet sorunlarının aşılmasında "bölgesel tarife" nin çözüm olup olamayacağının araştırılmasıdır. Çalışmada Eskişehir'de toplu taşıma faaliyetini yürüten ESTRAM işletmesinin Ekim 2019 verilerinden yararlanılmıştır. Bu veriler benzetim yoluyla Ekim 2020 verilerinin tahmin edilmesinde kullanılmış ve Ekim 2020 tahmini verileri ile bölgesel tarife oluşturulmuştur. Çalışmanın sonucunda; sağlık krizinin aşılmasında toplum için daha adil, esnek ve insan sağllğının ön planda tutulduğu bölgesel tarifeye geçilmesi gerektiği sonucuna varılmıştır.

Anahtar Sözcükler: COVID-19, Sağlık Krizi, Tramvay, Toplu Taşıma Maliyetleri, Bölgesel Tarife.

Makale Gönderme Tarihi: 20.06.2020

Makale Kabul Tarihi: 18.09 .2020

\section{Önerilen Atıf:}

Ekergil, V., Kodalak, E. (2020). COVID-19 Sağlık Krizinde Raylı Toplu Taşımadaki Maliyet Sorununa Bölgesel Tarife Önerisi: Eskişehir Uygulaması, İşletme Akademisi Dergisi, 1(3): 275-293. (C) 2020 İşletme Akademisi Dergisi. 


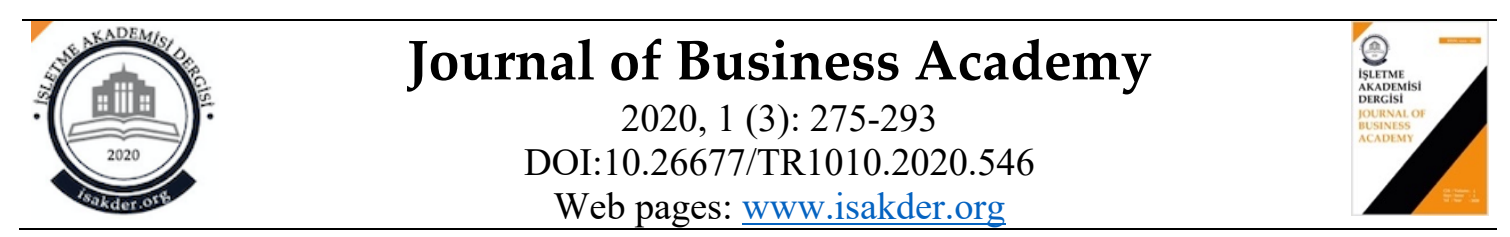

$\underline{\text { ResearchArticle }}$

\title{
Regional Tariff Proposal for the Cost Problem in Rail Public Transport During the COVID-19 Health Crisis: Eskişehir Application
}

\author{
Prof. Dr. Vedat EKERGIIL \\ Anadolu University, Faculty of Open Education, Eskişehir \\ vekergil@anadolu.edu.tr, https://orcid.org/0000-0002-6790-8529
}

\section{Erkan KODALAK}

SMMM, İstanbul

erkankodalak@gmail.com, https://orcid.org/0000-0001-5253-1194

\begin{abstract}
COVID-19 with settlement on the agenda in Turkey since March 11, 2020; many precautions such as "social distance", "transition to distance education in schools", "curfews under 20 and over 65", "abolishing the standing passenger practice in public transport and reducing the number of seated passengers" brought a new understanding to public transport. Even if all precautions were removed with the normalization process, the virus continued to make its presence felt throughout the summer period. So, by re-imagining the transportation system; It is necessary to move towards a more flexible, more efficient and uninterrupted structure. In this article, the financial and economic crisis caused by COVID-19 has been named as "health crisis". The aim of this study is to investigate whether the "regional tariff" can be a solution in overcoming the cost problems arising in public transportation with the health crisis. In the study, October 2019 data of ESTRAM company, which carries out public transportation in Eskişehir, was used. These data were used to estimate the October 2020 data through simulation, and the regional tariff was created with the October 2020 forecast data. As a result of the study, it was concluded that in overcoming the health crisis, the regional tariff should be adopted, which is more fair for the society, flexible and prioritizing human health.
\end{abstract}

Keywords: COVID-19, Health crisis, Tram, Public transport costs, Regional tariff.

Received: 20.06 .2020

Accepted: 18.09 .2020

\section{Suggested Citation:}

Ekergil, V., Kodalak, E. (2020). Regional Tariff Proposal for the Cost Problem in Rail Public Transport During the COVID-19 Health Crisis: Eskişehir Application, Journal of Business Academy, 1(3): 275-293.

(C) 2020 Journal of Business Academy. 


\section{GİRIŞ}

Sanayileşme ile birlikte ticaretin gelişmesi, büyümesi ve hızlanması, iş, eğitim ve sosyal amaçlı olarak insanların bir araya gelmesi şehir yaşamında yoğunlaşmaya neden olmuştur. Türkiye'de özellikle 1950'li yıllardan itibaren kırsal kesimden şehirlere doğru bir nüfus hareketliliği yaşanmıştır. 1980 yılından itibaren yaşanan serbest piyasa ekonomisi ile bu hareketlilik hız kazanmıştır. Öyle ki, 1927' de kırsalda yaşayan nüfusun toplam nüfus içindeki oranı \%75,8 iken, bu oran 2010 yılında tam tersine dönmüştür (Demir ve Çabuk, 2010: 194). Bu nüfus hareketliliği Türkiye'nin şehirlerdeki trafik sorununun çözümünde toplu taşımacıllğ Sadece İstanbul ve Ankara'nın günlük yolculuk sayısı 22 milyondur (Özçelik, 2011: 4). Şehir içi ulaşımda toplu taşıma oldukça önemli bir yere sahiptir. 2020 yılında ortaya çıan COVID-19 salgının ortaya çıkması ile birlikte sosyal mesafeli hayat anlayışı hüküm sürmektedir. Sağlık Bakanı Fahrettin Koca'nın 'Türkiye'nin normalleşme sürecindeki yeni hayatı' tanımında yer alan "...günlük hayatı riski minimalize edecek şekilde düzenlemek" (https://t24.com.tr) ifadesine bağlı olarak toplu taşımacılığı yeniden yapılandırmak gerekmektedir.

Belediyelerin temel görevlerinden biri de şehir içi toplu ulaşım olanaklarını sağlamaktır. Bu hizmeti yerine getirirken toplum sağlığını koruması gerekmektedir. Bu nedenle belediyeler COVID-19sürecinde ve sonrasında toplu taşımada toplum sağlığını koruyan bir yapıyı kurgulamak durumundadır. Bu durum toplu taşımanın birçok açıdan yeniden düzenlenmesini gerekli kılmaktadır. Belediyelerin toplu taşımayı yeniden düzenlemesi kapsamında; sefer başına taşınan yolcu sayısının azaltılması, seferdeki araçların vagon sayısının arttırılması, yoğun saatlerde birden fazla aracı aynı hatta yönlendirilmesi, araç ve durakların temizlenmesi gibi önleyici tedbirlerin alınması gerekmektedir. Tüm bu önlemler işletmenin maliyetlerini artıran unsurlardır. Toplu taşıma işletmelerinin salgına bağlı olarak ortaya çıkan bu maliyetlerin bir kısmı belediye veya devlet tarafından sübvanse edilebilir. Bununla birlikte sübvansiyona rağmen, toplu taşıma işletmelerinin uygulamakta olduğu 'sabit tarife' ile toplu taşıma faaliyetinin sürdürülebilirliği pek mümkün görülmemektedir.

Türkiye'de toplu taşıma işletmelerinin birçoğu gelirlerini sabit fiyat tarifesi üzerinden elde etmektedir. Bu tarifede; öğrenci, tam, ücretsiz kullanım, 65 yaş üstü vb. gibi kesimler için sabit fiyat üzerinden tarife oluşturulmaktadır. Bu tarifede yolculuğun uzunluğu, hangi saatlerde yolculuk yapıldığı, kullanım sıklığı gibi kriterler göz ardı edilmektedir. COVID-19 sonrası da kontrollü sosyal hayat sürdürülmeye devam edeceği düşünülmektedir. Yeni koşullar altında toplu taşıma işletmelerinin faaliyetlerini yeni düzene göre sürdürmesinde de 'sabit tarife' yetersiz kalacaktır. Bu kapsamda toplu ulaşım tarife türleri arasında bölgesel ücret tarifesinin öne çıkacağı öngörülmektedir. Bölgesel ücret tarifesi, toplu taşıma hatlarının belirli kriterlere göre bölünmesi temeline dayanmaktadır. COVID-19 ortaya çıkardığı koşullarda toplu taşıma fiyat sisteminin; adaletli, mesafeye dayall, yolcu yoğunluğu ile orantıll, bölgesel unsurları göz önünde bulunduran esnek bir tarife ile yeniden kurgulaması gerekmektedir.

$\mathrm{Bu}$ kapsamda çalışmanın amacı, COVID-19 sonrası normalleşme sürecinde toplu taşıma tarifesinin "bölgesel tarife"ye dönüştürülmesi ile toplu taşıma hizmetinin sosyal başabaş noktasında hizmet sunulmasının sağlanmasıdır.

\section{YÖNTEM}

\subsection{Araştırmanın Yöntemi}

$\mathrm{Bu}$ çalışmada kullanılan araştırma yöntemi benzetimdir. Benzetim, dinamik bir sistemin özelliklerini ve davranışlarını bilgisayar aracılığıyla değerlendiren bir tekniktir. İncelenen gerçek bir hayat sisteminin belli bir zaman diliminde istenilen gerçek karakteristiklerini tahmin etmek amacıyla sistemin matematiksel, mantıksal bir modelinin geliştirilmesi ve bu sistem üzerinde 
deneyler yapılması sürecidir. Analitik yaklaşımların aksine benzetim modelleri karmaşık problemlerin modellenmesi ve çözümünde daha başarılı olduğu düşünülmektedir. Benzetim modellerinde, değişkenler arasındaki etkileşimleri gözlemek daha kolay olmakla beraber yoğun bilgisayar kullanımını gerektirmektedir. Gerçek sistemden toplanan bilgiler, bilgisayarda geliştirilen modellere uygulanarak sayısal birtakım sonuçlara ulaşmak hedeflenir(http://www.ozelogretim.hacettepe.edu.tr). Ulaştırma alanında benzetim yöntemi sıklıkla kullanılmıştır. Zorlu (2008) ulaşım planlamasında yolculuk talebinin belirlenmesine yönelik yaptığı araştırmada; ulaşım planlarının hazırlanmasında sosyoekonomik, fiziksel yapı ve benzetim modelinin içinde barındırdığı belirsizlikler planın hedefine ulaşmak için önemli olduğunu belirtmektedir. Keskin (2020), yapılan akademik çalışmalar incelendiğinde simülasyon yönteminin 22 farklı alana kullanıldığı belirlemiştir. Bu çalışmaların \%7'si ise ulaşım sistemleri ile ilgili çalışmaları oluşturmaktadır. Ulaşım sistemlerine yönelik çalışmalarda benzetim yöntemi genellikle şehir içi lojistik, şehir içi trafik düzenlemeleri ve tasarımı konularında kullanıldığı görülmektedir. Bu çalışmada ise, Eskişehir Tramvay'ın sabit tarifesinin bölgesel tarifeye dönüştürülmesi sonucunda, işletmenin bugün ve geleceğe dönük kararlarına katk1 sağlanmasında benzetim yönetimden yararlanılmaktadır (Çörekçioğlu ve Sezen, 2011:2). Benzetim yönteminin şehir içi ulaşım gelir ve maliyet yönetimi üzerinde uygulanmış olması, çalışmaya özgünlük katacağı düşünülmektedir.

\subsection{Araştırmanın Evreni ve Veri Toplama Aracı}

Türkiye'de son 20 yılda şehirlerin özellikle raylı toplu ulaşım sistemlerine geçtiği gözlemlenmektedir. Nitekim birim yolculuk talebi bakımından raylı sistemler ile karayolu sistemleri karşılaştırıldığında raylı sistemlerin yaklaşık 5,5 kat daha fazla tercih edildiği araştırmalarla ortaya konulmaktadır (Öztürk ve Öztürk, 2010: 6).

Bu çalışma, Türkiye'deki raylı toplu taşıma işletmelerinin tarifelerinin analizi, genel olarak kullanılmakta olan sabit tarife sistemlerinden esnek tarifelere geçişi ve oluşacak maliyet-gelir dengesi, sosyal olarak ihtiyaç duyulan esnek tarifeler ile işletmenin sürdürülebilirliğinin değerlendirilmesi bakımından önem taşımaktadır. Bu çalışma; Türkiye'de toplu taşıma faaliyetini yürüten işletmelerden talep edilmesine rağmen, veri temin edilememesi nedeniyle Eskişehir Tramvay (ESTRAM) ile sınırlı kalınmıştır. Çalışma, Eskişehir'de toplu taşıma faaliyetini yürüten Eskişehir Büyükşehir Belediyesi'nin tramvay ile toplu taşıma hizmeti veren Eskişehir Tramvay'ın 2019 yılına ait gerçek veri setine dayalı olarak gerçekleştirilmiştir.

\subsection{Verilerin Analizi}

Çalışmanın temelini oluşturan verilerin ilgili kaynaklardan toplanması, verilerin birleştirilmesi ve analize uygun olacak şekilde verinin dönüştürülmesi aşamaları veri hazırlamayı oluşturmaktadır (Ekergil ve Ersoy, 2016: 161). Bu yönde veriler, Eskişehir Tramvay'ın muhasebe ile istatistik bölümlerinden elde edilmiştir. Bu veriler; durak ve saat bazında yolcu türü sayıları ile temel maliyetlerdir. Yolcu sayıları sabit tarifeden yararlanarak işletmenin elde etmiş olduğu gelire dönüştürülmüştür. İşletme gelirleri yolcu türünde, durak ve saat bazında ilk biniş temelinde sınıflandırılmıştır. İşletme gelirleri ile maliyetler sosyal başabaş noktası varsayımında söz konusu sınıflama ile eşleştirilmiştir. Tüm bu işlemler için Excel 2013 programından yararlanılmıştır. Bu veri seti daha sonra Eskişehir Tramvay'ın tarafından kontrol edilerek, güvenilirlik ve geçerlik sağlanmıştır. İşletmeden alınan veriler, Excel 2013 programı yardımcıyla bölgesel tarife önerisine ilişkin yeni veri setine dönüştürülmüştür. Tarife önerisinde, Eskişehir raylı toplu taşıma hatları gelecekteki gelişmeleri de göz önünde bulundurularak beş bölge de tanımlanmıştır. Gelecekte yaşanacak gelişmelere bağlı olarak hem bölgelerde hem de tarifede olası değişikliklerin yapılabilmesi için, Excel üzerinde entegre çalışan bağlantılı tablolar formüller yardımıyla birbirine bağlanmıştır. Böylece Excel veri giriş tablosunda yapılacak bir değişiklik, tüm çözüm modelini değiştirmektedir. 


\section{BULGULAR}

Tramvay toplu taşıma sisteminde maliyetleme ve fiyatlandırma hakkında kısaca bilgi verildikten sonra bölgesel tarife sistemi ile Ekim 2019 verileri benzetim yoluyla Ekim 2020 modellenerek tramvay sisteminin beş bölge için bölgesel tarife önerisi oluşturulmuştur.

\subsection{Raylı Sistemlerde Maliyetler}

Maliyetler; etkilerin, gelişme veya güncelleştirmelerin muhasebe dilinde sayısallaştırılmış halidir. Örneğin; COVID-19 nedeniyle ortaya çıkan "toplu taşıma araçlarında \%50 doluluk" kuralının uygulanması pandemi ile mücadele için bir gerekliliktir. Ancak bu etki ölçülebildiği ve karşılaştırılabilirliği maliyet kavramı ile açıklanmaktadır. Maliyet kavramı, kaynakların kullanımı hakkında denge kurmayı ifade etmektedir (Litman, 2009: 7). Yolcu tarafından karşılanan maliyetler "iç maliyetler", yolcu olmayanlar tarafından karşılanan maliyetler ise diş maliyetler" olarak ifade edilmektedir. Topluma yansiyan bu iki maliyetin toplamı ise sosyal maliyetleri oluşturmaktadır (Litman, 2009: 11).

İç maliyetler, işletim maliyetlerini içermektedir. Dış maliyetler ise; çevresel ve dış kaynaklı etkiler (hava kirliliği, iklim değişikliği, gürültü, doğa ve manzaradaki bozulma, COVID-19 vb.), şehir alanına ilişkin ek maliyetler (bariyer etkileri, yer darlığı vb.), kazalar (tıbbi bakım, üretim kayıpları, acı ve üzüntü vb.) ve trafik (zaman kayıpları ve artan işletim maliyetleri vb.) gibi unsurlardan oluşmaktadır (EEA, 2001: 10). Çalışma iç maliyetleri kapsamaktadır.

\subsection{Raylı Sistemlerde Fiyatlandırma}

Fiyat, bir işletmenin satışlarını ve kârlılı̆̆ını belirlemeyen önemli bir değişkendir. İşletme yaptığı satışlara bağlı olarak kârını değiştirebileceği için, fiyat kararları önemli bir yönetici yeteneğidir. İşletme yöneticisi hem tüketiciyi hem de çeşitli çıkar gruplarını göz önünde bulundurarak ürün fiyatlarını belirlemek durumundadır (Çakır Yıldız: 117.).

Toplu taşıma hizmetlerinde fiyat politikasının uygulanmasında; toplu ulaşım kullanım düzeyi, kâr, sosyal hedefler, ekonomik hedefler ve yerel halkın desteği önemli unsurlardır. Toplu taşıma hizmeti veren yerel yönetimin bu unsurlara vermiş olduğu öneme veya ortaya koyduğu hedefe bağlı olarak fiyat tarifesi oluşturulabilir (Benk ve Akdemir, 2010: 132).

Raylı sistemlerde yukarıda belirtilen hedefler kapsamında farklı tarifeler uygulanmaktadır. Fransa Çevre, Sürdürebilir Kalkınma ve Enerji Bakanlığı (MEDDE) ve Fransız Kalkınma Ajansı (AFD)'nın yayımladığ 1 “Kentsel Ulaşımın Finanse Edilmesinde İyi Uygulamalar Kılavuzu” bu alanda uygulanabilecek tarifeleri aşağıdaki gibi sıralamaktadır (Allairevd., 2014: 38, 39):

\section{- Sosyal destek tarifelendirmesi}

Kamusal toplu taşımacılığının finanse edilme ihtiyacı olsa da genellikle öğrenciler, işsizler, yaşlılar gibi belirli müşteri gruplarını hedef alan özel fiyatların oluşturulması yaygın olarak kullanılmaktadır. Ancak, son zamanlarda sosyal kategori yerine gelir düzeyine dayanan bir fiyat sistemi üzerinde durulmaktadır.

\section{- Sürekli yolcular ve geçici yolcular}

Tek bir bilet alan yolculardan farklı olarak haftalık ve aylık bilet alan yolcular için indirim uygulanmaktadır. Bu tür indirimler ayrıca yolcuların sadakatini ve toplu taşıma kullanım oranlarını artırmaktadır. Bununla beraber yolcu için birim fiyatın azalması, işletme için gelir düşüşüne neden olmaktadır.

\section{- Tek fiyat tarifesi.}


Şehir içi toplu ulaşımın kapsadığı alan boyunca aynı olan tarifedir. Bu tarife yönetim açısından kolay olmakla beraber uzun mesafelerde seyahat edenler için elverişli görülmektedir. Kısa mesafe yolcularına fazla fiyat yükleyen bu tarife özellikle şehrin genişlemesini destekler niteliktedir.

\section{- Kilometreye dayalı tarife.}

Bu sistem maliyetle orantılı gelir elde etmeyi amaçlamaktadır. Uygulaması karmaşık, genel olarak maddi gücü daha az olan ve şehirden uzakta yaşayanlar için etkin bir yöntem olabilmektedir. Washington ve Tokyo'da mesafeye dayalı fiyatlandırma uygulanmaktadır.

\section{- Durak bazlı tarife.}

İşletmenin ihtiyaçları ve şehir politikası seçimi arasında uzlaştırıcı bir rol oynamaktadır. Bu sistem coğrafik bölgeleri iki yaklaşıma göre ayırmaktadır:

- Eşmerkezli halkalar: Merkez bölgeden seyahat edilen bölgelerin mesafesine dayalı olarak tarife oluşturulur. Genellikle geniş büyük şehir alanları için uygulanmaktadır.

- Bölgeden bölgeye: Toplu taşıma sistemi genel olarak bölgelere ayrılmaktadır. Geçilen bölge sayısına göre bölgeden bölgeye fiyatlandırma yapılmaktadır. Genellikle çok merkezli büyük şehir alanları için uygulanmaktadır.

\section{- Saat dilimi bazlı tarife.}

Günlük yolcu yoğunluğu saat dilimlerine göre farklllık gösterebilmektedir. Saat dilimlerinin yoğun veya az yoğun saatlerine bağlı olarak değişken tarifeler oluşturulmaktadır. Bu tarifenin kullanılması durumunda yoğun saat dilimleri için daha fazla yatırım yapmak yerine, bu saatlerde yolculuk yapma zorunluluğu olmayanları caydırma yolunu tercih etmektedir.

Raylı sistemlerde kullanılan tarife türleri Tablo 1'de özetlenmektedir:

Tablo 1. Raylı Sistemlerde Kullanılan Tarife Türleri

\begin{tabular}{|c|c|}
\hline Kullanıcı bazında & $\begin{array}{l}\text { - Sosyal destek (çocuk, genç, öğrenci, işsiz vb.) } \\
\text { - Sürekli yolcu } \\
\text { - Geçici yolcu }\end{array}$ \\
\hline Yolculuk bazında & $\begin{array}{l}\text {-Tek kullanım } \\
\text { - Kilometre kullanımı } \\
\text {-Durak kullanımı } \\
\text { - Bölge kullanımı }\end{array}$ \\
\hline Zaman bazında & $\begin{array}{l}\text {-Yoğun zamanlar } \\
\text { - Yoğun olmayan zamanlar } \\
\text { - Hafta içi ve sonu } \\
\text { - Belirli üst limit }\end{array}$ \\
\hline Ücretsiz tarife & $\begin{array}{l}\text {-Kullanıcı tarafından direkt bir ödeme olmaması } \\
\text { durumu }\end{array}$ \\
\hline
\end{tabular}

Türkiye'de 2020 yılı itibarıyla Ankara, Samsun, Eskişehir, İstanbul, Bursa, İzmir, Kayseri, Gaziantep, Konya, Adana, Kocaeli ve Antalya olmak üzere 12 şehirde; hafif raylı sistem, metro, tramvay, banliyö ve füniküler sistemlerinden biri veya birkaçı kullanılmaktadır. Türkiye'deki 
hafif raylı sistemlerin tarifeleri genellikle kullanıcı bazında tarife şeklindedir. Bu kapsamda; tam, öğrenci ve sosyal amaçlı sabit fiyatlı tarife ile sınırlı / sınırsız sefer sayılı abonman tipi tarife yapıldığı görülmektedir. Bunların dışında, Türkiye'de 2002 yılından itibaren65 yaş ve üzeri kişiler ücretsiz olarak taşınmaktadır (http://www.mevzuat.gov.tr). Böylece belirli bir kesim için sosyal destek tarifelendirmesi gerçekleştirilmektedir.

11 Mart 2020 itibariyle COVID-19'un ortaya çıkmasıyla birlikte başta T.C. Sağlık Bakanlığı ve belediyeler toplum sağlığını korumak adına birçok karar almıştır. Belediyeler tarafından alınan kararlardan biri de 65 yaş ve üzeri kişiler için olan ücretsiz tarifenin kısıtlanmasıdır. Bunun en önemli nedeni 65 yaş ve üzeri hastalarda bağışıklık sistemin zayıf olması ve eşlik eden hastalıkların ise riski arttırmasıdır. Japonya'da toplam 1772 toplum kökenli pnömoni (TKP) atağının incelendiği çok merkezli bir çalışmada, erişkin TKP insidansı $\% 16,9$ olarak saptanmış; 65-69 yaş grubundaki görülme sıklığının 15-64 yaş grubundakilerin üç katı, 85 yaş üzerindeki kişilerin ise 10 katı olduğu tespit edilmiştir (Öztürk, Kınıklı ve Cesur, 2015: 64; Ak, 2019: 126). COVID-19 salgınının ne zaman biteceğine ilişkin kesin bir bilgi bulunmamaktadır. Yirminci yüzyılın başında ortaya çıkan İspanyol gribi 50 milyondan fazla insanın ölümüne yol açmış ve 18 ay sürmüş̧ür. 2009'da görülen A H1N1 virüsünün İspanya, Almanya ve İngiltere'de zirveyi yaz aylarında görmüştü. COVID-19 hastalığına karşı tedavi yöntemleri geliştirmek için dünyanın dört bir yanında araştırmacılar çalışmalarını sürdürmektedir. Ancak uzmanlar, salgından gerçek anlamıyla kurtulabilmek için COVID-19'a karşı aşı geliştirilmesi gerektiğini ve bunun da en az 12 ila 18 ay alacağını bildirmektedir (Koyuncu, 26/04/2020). Bu kapsamda belediyelerin 65 yaş ve üzeri kişilere uygulanan ücretsiz tarifeyi geçici ya da tamamen kaldırılması veya bazı kısıtlamalar yapması söz konusu olabilir.

\subsection{Bölgesel Tarife Sistemi}

T.C. Sağlık Bakanlığı COVID-19 ile olan mücadelesini "saha incelemesi/filyasyon" temeli üzerine kurmuştur. Filyasyon, kaynağın ve etkenin belirlenmesine yönelik çalışma yapılması ve/veya temaslılar dahil koruma ve kontrol önlemlerinin alınmasıdır (Bulaşıcı Hastalıklar İle Mücadele Rehberi: 5). Böylece COVID-19'a yakalanan bir kişinin kimlerle temas halinde olduğunu saptamaya yönelik yapılan saha incelenmektedir. Ayrıca bu önlemler kapsamında bilişim ve mobil teknolojisi olanaklarından faydalanılarak, tüm hastalık sürecini kontrol ve takip eden "Hayat Eve Sığar" mobil uygulaması oluşturmuştur. Mobil uygulaması ile kullanıcının bulunduğu bölgenin riskli olup olmadığına ilişkin yoğunluk haritası verilmektedir. Yoğunluk haritasinda "Evde İzolasyon", "Riskli" ve "Enfekte" olarak sinıflandırılmaktadır(www.hurriyet.com.tr). Ayrıca İçişleri Bakanlığı tarafından24 Mayıs 2020 'de yayımlanan genelgede “... toplu taşıma araçları, geçici bir süreliğine araç ruhsatında belirtilen yolcu taşıma kapasitesinin \%50'si oranında yolcu kabul edecek" ifadesi yer almaktadır (https://www.icisleri.gov.tr). Bu durumda toplu taşıma araçlarında taşıma kapasitesinin azaltılması ve bölgesel yoğunlukların etkin bir şekilde yönetme görevi belediyelere düşmektedir. Çalışmada, belediyelerin sabit tarifeden "bölgesel tarife" ye geçerek, toplu taşımadaki yoğunluğu daha iyi bir şekilde yönetebileceği tezi savunulmaktadır.

"COVID-19 Normalleşme Planı", 4 Mayıs 2020'de T.C. Cumhurbaşkanlığı tarafından salgının seyrine bağlı olarak değişime açık bir şekilde hazırlanmıştır. Bu plana göre; 27 Mayıs 2020'den itibaren sokağa çıkma kısıtlamasında "yaş kısıtlamaları tamamen kaldırılacaktır", 1 Ağustos 2020 'den itibaren eğitimler ve kursların devamlılığ sağlanacak, 24 Ağustos 2020'den itibaren özel ve resmi eğitim kurumlarının (anaokulu, ilk, orta ve lise) telafi eğitim yapabilecek, kamu yararına hizmet veren vakıf ve dernek yurtları ve 1 Eylül 2020'den itibaren üniversitelerin başlamasıyla birlikte açılacağı bildirilmektedir. Yayımlanan planda şehir içi toplu taşıma araçlarının sınırlı kapasite ile işletilmesinin kaldırılmasına ilişkin bir hüküm bulunmamaktadır. 
İçişleri Bakanlığı'nın şehir içi çalışan toplu taşıma araçlarına yönelik genelgesinde ise sınırlı kapasite, araç kapasitesinin \%50'si olarak tanımlanmaktadır (https://www.ardesentso.org.tr). 1 Eylül 2020 tarihinden sonra normalleşme sürecine geçişin son aşamasında tüm yasakların kalkacağını düşünülmektedir. Ancak Eylül 2020'den itibaren tüm dünyada COVID-19 ikinci dalga ortaya çıkmaya başlamış ve kısıtlamalar tekrar gelmeye başlamıştır. Toplu taşıma ulaşımında ayakta yolcu uygulamasına ise izin verilmemektedir. Böyle bir durumda belediyeler; özellikle yoğun saatlerde seferlerin artırılması, tramvaydaki katar sayısının artırılması, belirli saatlerdeki biniş ücretlerinin artırılması gibi önlemler alınabilir. Bu önlemler büyük bir olasılıkla maliyetlerde de bir artsşa neden olacaktır. Böyle bir ortamda belediyelerin bölgesel tarife sistemini uygulamaya başlaması, sürecin yönetilmesine önemli bir dinamiklik kazandıracaktır. Bu kapsamda çalışmanın birinci kısmında Ekim 2019 ile Ekim 2020 (varsayımlara dayalı olarak belirlenen) dönemleri karşılaştırmış ve bir COVID-19benzetimi (simülasyon) gerçekleştirilmeye çalışılmıştır. Çalışmanın ikinci kısmında ise COVID-19 sonrası yaşamda toplumun tüm kesimlerinin çıkarlarını koruyacak bir çözüm önerisi olarak Eskişehir Tramvay için bölgesel tarife önerisi oluşturulmuştur.

\subsubsection{Eskişehir Tramvay'ın Ekim 2019'un Ekim 2020'ye Benzetimi}

Belediyelerin COVID-19 mücadelesi kapsamında uygulayabileceği bölgesel tarife önerisi, Eskişehir Tramvay verilerine dayanarak oluşturulmuştur. Eskişehir Tramvay'ın kamusal toplu taşıma hizmeti veren bir şirket olması nedeni ile fiyatlamada kâr elde etme amacı bulunmamaktadır. İşletmenin amacı; toplumun ulaşım ihtiyacını karşılamak, mevcut ve gelecekteki yatırımları finanse etmek ve işletim faaliyetlerini kaliteden ödün vermeden yürütmektir. İşletme bu amaçlarını yerine getirirken, Belediyenin garantörlüğünde uygun faizli yurt içi ve yurt dışı kredi olanaklarından yararlanabilmektedir. Belediye bazı durumlarda ise işletmenin elde etmiş olduğu gelir fazlasını talep etmeyerek, yatırıma dönüştürmesine izin vermektedir. Bu nedenlerle işletmenin uygulamış olduğu fiyatlandırma politikası sosyal başabaş noktası temelinde oluşturulmaktadır.

Eskişehir Tramvay işletmesi 7 hat ve 61 duraktan oluşan şehir içi raylı toplu taşıma sistemidir. Toplam hat uzunluğu 48 km'dir. Diğer şehirlerde olduğu gibi tarifesini kullanıcı bazlı olarak sabit tarife üzerinden gerçekleştirmektedir. Eskişehir Tramvay, 2019 yılında423.680 sefer (pratik kapasite) ile 41.222.395 yolcu (sefer başına ortalama 97,3 yolcu) taşımıştır. Eskişehir Tramvay, 2019 yılı aylık seferlerinin dağılımı incelendiğinde; Ekim 2019'da planlanan 37.773 seferken 37.703 gerçekleşmiş ve 3.937.770 yolcu ile yılın en yüksek yolcu sayısına ulaşıldığı görülmüştür (http://www2.estram.com.tr). Eskişehir Tramvay'ın yıllar itibariyle yolcu türüne göre toplam içindeki oranları çok küçük oranlarda değişim göstermiştir. Buna göre toplam yolcuların; \%48'i tam, \%32'si indirimli ve\%20'si serbest/ücretsizdir (bu oran içindeki yer alan 65 yaş ve üstü yolcular toplam içinde \%13'lük bir orana sahiptir). COVID-19 sonrası normalleşme sürecinde birçok alanda olduğu gibi toplu taşımacılıkta da salgınla mücadele tedbirleri alınmaktadır. Çalışmada bu önlemlere ilişkin olarak bazı varsayımlar kurgulanmıştır:

- Tramvayın seferdeki kapasitesi 72'si koltuk olmak üzere 216 kişidir. Alınan önlemler kapsamında ayakta yolculuk yapılmasına izin verilmeyeceği varsayılmaktadır.

- 65+ yaş ve üzeri yolcular ücretsiz yolcu niteliğindedir. COVID-19 salgınında en riskli grup 65 yaş ve üstü kabul edilmektedir. Bu gruptaki yolcuların zorunlu durumlar dışında yolculuk yapmalarına izin verilmeyeceği öngörülmektedir. Bu kapsamda ücretsiz yolculuk yapabilen bu gruba0,10 TL/yolcu gibi küçük bir yolculuk bedeli konulması durumunda, bu grupta yolcu sayısının \%30 azalacağı varsayılmaktadır.

- Tam olarak yolculuk yapanların bir kısmının COVID-19 nedeniyle kendi özel araçlarını tercih edeceği ve bir kısmının da bu salgını evlerinde çalışarak geçireceği 
düşünülmektedir. Bu nedenlerle bu yolculuk türünde yolcu sayısının \%4 azalacağı varsayılmaktadır.

- Her bir sefere kabul eden yolcu sayısınin azaltılması [(3.937.770 yolcu / 37.773 sefer) sefer başına 104,25 yolcudan 72 yolcuya indirilmesi) nedeniyle aylık sefer sayısının artacağı varsayılmaktadır.

- Sefer sayısının artmasıyla birlikte toplam değişken maliyetlerde ve birim sabit maliyette bir artışa neden olacağı ve ortaya çıkacak bu ek maliyetlerin Eskişehir Tramvay veya devlet tarafından karşılanacağı varsayılmaktadır.

Bu varsayımlar altında yolculuk türü bazında Ekim 2019 ve Ekim 2020 (tahmini) verileri Tablo 2'de verilmektedir.

Tablo 2. Ekim 2019 ve Ekim 2020 Dönemlerinin Yolcu Sayıları Ve Gelirleri

\begin{tabular}{|c|c|c|c|c|c|c|c|}
\hline \multicolumn{2}{|c|}{ Yillar / } & Esbilet & Eskart Tam & $\begin{array}{c}\text { Eskart } \\
\text { İndirimli }\end{array}$ & $\begin{array}{c}65 \text { Yaş ve } \\
\text { Üzeri }\end{array}$ & $\begin{array}{c}\text { Diğer } \\
\text { İndirimli }\end{array}$ & Toplam \\
\hline \multirow{3}{*}{ 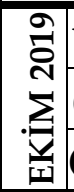 } & Yolcu Sayısı & $550.586 y$ & $1.525 .690 \mathrm{y}$ & $1.141 .347 y$ & $437.062 \mathrm{y}$ & $283.085 y$ & $3.937 .770 \mathrm{y}$ \\
\hline & $(\times)$ Tarife $^{*}$ & 2,70 TL/y & 2,00 TL/y & 1,35 TL/y & $0,00 \mathrm{TL} / \mathrm{y}$ & $0,00 \mathrm{TL} / \mathrm{y}$ & \\
\hline & (=) Toplam Gelir & 1.486 .581 & 3.051 .380 & 1.540 .818 & 0 & 0 & 6.078 .779 \\
\hline \multirow{3}{*}{ 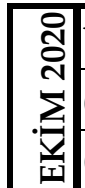 } & Yolcu Sayısı & 528.562 y & $1.464 .662 \mathrm{y}$ & $1.141 .347 \mathrm{y}$ & $305.944 \mathrm{y}$ & $283.085 \mathrm{y}$ & $3.723 .600 \mathrm{y}$ \\
\hline & $(\times)$ Tarife* & 2,70 TL/y & $2,00 \mathrm{TL} / \mathrm{y}$ & 1,35 TL/y & $0,00 \mathrm{TL} / \mathrm{y}$ & $0,00 \mathrm{TL} / \mathrm{y}$ & \\
\hline & (=) Toplam Gelir & 1.447 .118 & 2.929.324 & 1.540 .818 & 0 & 0 & 5.917 .260 \\
\hline
\end{tabular}

Kaynak: Eskişehir Tramvay verilerinden derlenmiş ve benzetim edilmiştir.

Tablo 2 incelendiğinde; Eskart indirimli ve diğer indirimli (polis, zabıta, gazeteci vb.) yolcu sayılarında ve gelirlerinde bir değişim yaşanmadı ğı görülmektedir. Ancak Esbilet, Eskart tam ile 65 yaş ve üzeri tarifelerinde hem yolcu sayısı hem de gelirlerinde bir değişim söz konusudur. Bu durum iki dönem arasında iki farklı sonucun ortaya çıkmasına neden olmaktadır:

(1) İki dönemin toplam gelirleri arasında161.519 TL'lik (6.078.779 - 5.917.260) bir azalma oluşmaktadır. Bu gelir farkı; ya Eskişehir Tramvay/Belediye tarafından karşılanacak ya 2020 yılı maliyet artışı ve gelir kaybı olarak görülerek UKOME aracılığıyla tarife ücretlerinde değiş̧ikliğe gidecek ya da yeni ücretlendirmeye başladığ 65 yaş ve üzeri yolcuların tarife ücretini daha yüksek bir değerden belirlenerek ortadan kaldırılacaktır (0,10 TL/yolcu gibi. Pandemi döneminde İl Hifzissihha Kurulu'nun 17/08/2020 tarihinde aldığ kararla 65 yaş ve üzeri vatandaşların 07.00 - 09.00 ile 17.00 - 19.00 saatleri arasında toplu taşıma araçların kullanmamaları tavsiye edilmiştir).

(2) Eskişehir Tramvay, Ekim 2019'da yılın en fazla sayıda seferini gerçekleştirmiş ve böylece en fazla sayıda yolcusunu taşımıştır. Eskişehir Tramvay'ın ilgili ayda planladığı sefer kapasitesi 37.773'tür. Böyle bir durumda her seferde ortalama 104,25 yolcu taşıyabilmektedir. Ancak Ekim 2020'deki COVID-19 önlemleri sonucunda ortaya çıkan sefer başına ortalama 72 oturan yolcu koşulunun yerine getirilebilmesi için bu aydaki toplam sefer sayısının 51.717'e çıkarılması gerekmektedir. Bu sorunun çözümlenebilmesi aşağıdaki yöntemler önerilmektedir:

- Eskişehir Tramvay yeni tramvaylar satın alınabilir. Bu yolun tercih edilmesi durumunda COVID-19 salgınının bitmesinden sonra da bu tramvaylar yeni hatlarda 
kullanılabilir. Ancak yeni tramvayların satın alınması işletmenin yatırım maliyetinin artıracaktır. Ayrıca bu işlem uzun bir sürecin sonunda gerçekleştirilebilir ki tramvaylar hemen kullanılmak istenmektedir.

- Eskişehir Tramvay'ın bazı hatlarında taşınan yolcu sayısı ortalamanın çok altındadır. Bu hatlardaki tramvaylar yoğun hatlara yönlendirilebilir. Yoğun hatlardaki seferler arasındaki zaman aralığı azaltılarak sefer sayısı arttırılabilir. Tramvay hatları şehirdeki araç yolları üzerine yapılmıştır. Tramvay sefer sayısının arttırılması, şehirdeki araç trafiğinin kilitlenmesine neden olacaktır.

- Tramvaya yoğun talebin olduğu saatlerde, iki tramvay katarı birbirine bağlı bir şekilde trafiğe çıkartılabilir. Böylece bir seferde 72 oturan yolcu değil, 144 oturan yolcu taşınmış olacaktır.

- 'Sokağa çıkma sınırlamaları', 'esnek çalışma' veya 'kademeli çalışma' gibi hükümetin alacağı kararlar ile yolcu sayısı azaltılabilir.

\subsubsection{Sağlık Krizinde Bölgesel Tarife Sistemi Uygulanması}

1929'da Büyük Buhranla başlayan, 2. Dünya Savaşı (1944) ve küresel sistemik ekonomik/finansal krizle (2009) devam eden yüzyıl krizlerin, sonuncusu COVID-19 salgınıdır (2020). Uluslararası kuruluşlar dünya ekonomisinin 2020'de \%5 küçüleceği öngörmektedir. İstihdamda sert daralmalar, küresel borçlulukta artışlar, gelir dağılımındaki bozulmalar ve tedarik zincirlerinde sıradanlaşan aksamalar görülebilecektir (Alkan, 02/10/2020). COVID-19 sonuçları bakımından ülkeleri ekonomik, siyasi ve finansal olarak doğrudan etkilemektedir ve bu nedenle makalede bu kriz bir "sağlık krizi" olarak adlandırılmaktadır. TUIK verilerine göre; "GSYH 2020 yılı ikinci çeyrek ilk tahmini; zincirlenmiş hacim endeksi olarak, bir önceki yılın aynı çeyreğine göre \%9,9 azaldı̆̆ı" ifade edilmektedir. Ayrıca bu azalışın en önemli kalemlerinden birisi de hizmet sektöründe gerçekleşmiştir (TUIK, Sayı: 33605, 31/08/2020). Toplu taşıma da hizmet sektörünün bir parçasıdır.

Türkiye'de sağlık krizi ile birlikte; öğrencilerin okulların tatil edilmesi, sokağa çıkma kısıtlamaları, kamu kesimi çalışanlarının evde kalması, 65 yaş üstü için sokağa çıkma yasağı getirilmesi gibi önlemler ile birlikte toplu taşıma talebinde önemli düşüş ortaya çıkmıştır. Ayrıca toplu taşıma sistemlerinin sadece \%50 seviyesinde yolcu taşıyabilmesine izin veren yasal düzenleme nedeniyle işletmenin gelirleri dip seviyeye ulaşmıştır. Bu sorunların aşılması ve Hükümetin sağlık krizine yönelik talep ettiği değişiklere dinamik bir şekilde yanıt verebilmesi için bölgesel tarife önerilmektedir. Bu kapsamda çalışmada; öncelikle toplu taşımanın yapıldığı hatlar üzerinden bölgeler tanımlanmakta ve sonrasında da bölgelerin özelliklerine dayalı olarak yeni bir tarife ortaya konulmaktadır.

\subsubsection{Bölgelerin Tanımlanması}

Eskişehir 1993 yılında büyükşehir statüsüne çıkarılmasına rağmen 2000'li yılların ortalarına kadar "şehir merkezi" yapısından kurtulamamıştır. Resmî kurumlar, stadyum, bankalar, alışveriş yerleri, gezi alanları vb. hep şehir merkezinde kurgulanmıştır. Bu nedenle Eskişehir halkındaki genel anlayış her işin şehir merkezinde çözümleneceğine ilişkindir. Her ne kadar son 15 yıldır gerek hükümet gerekse Büyükşehir ve alt belediyelerin çalışmalarıyla bu alışkanlık ortadan kaldırılmaya çalışılsa da henüz şehir merkezinin yoğunluğu azalmış değildir. Bu nedenle Eskişehir Tramvay'ın güzergâh haritası incelendiğinde, şehir merkezi odaklı bir yapının olduğu göze çarpmaktadır. Eskişehir Tramvay'ın bölgelerinin tanımlanmasında, tramvay durakları esas alınmıştır. Durakların; yolcu sayıları, gelirleri, coğrafik konumu, hat hareketliliği gibi unsurlar bölgelerin tanımlanmasında etkin rol oynamıştır. Öncelikle "Bölge 0 (Merkez)" belirlenmiş ve sonrasında merkez etrafında diğer bölgeler konumlandırılmıştır. Bu kapsamda Eskişehir 
Tramvay'ın hatları altı (6) farklı bölgeye ayrılmış ve bu durum 1. Şekil'deki harita üzerinde gösterilmiştir.

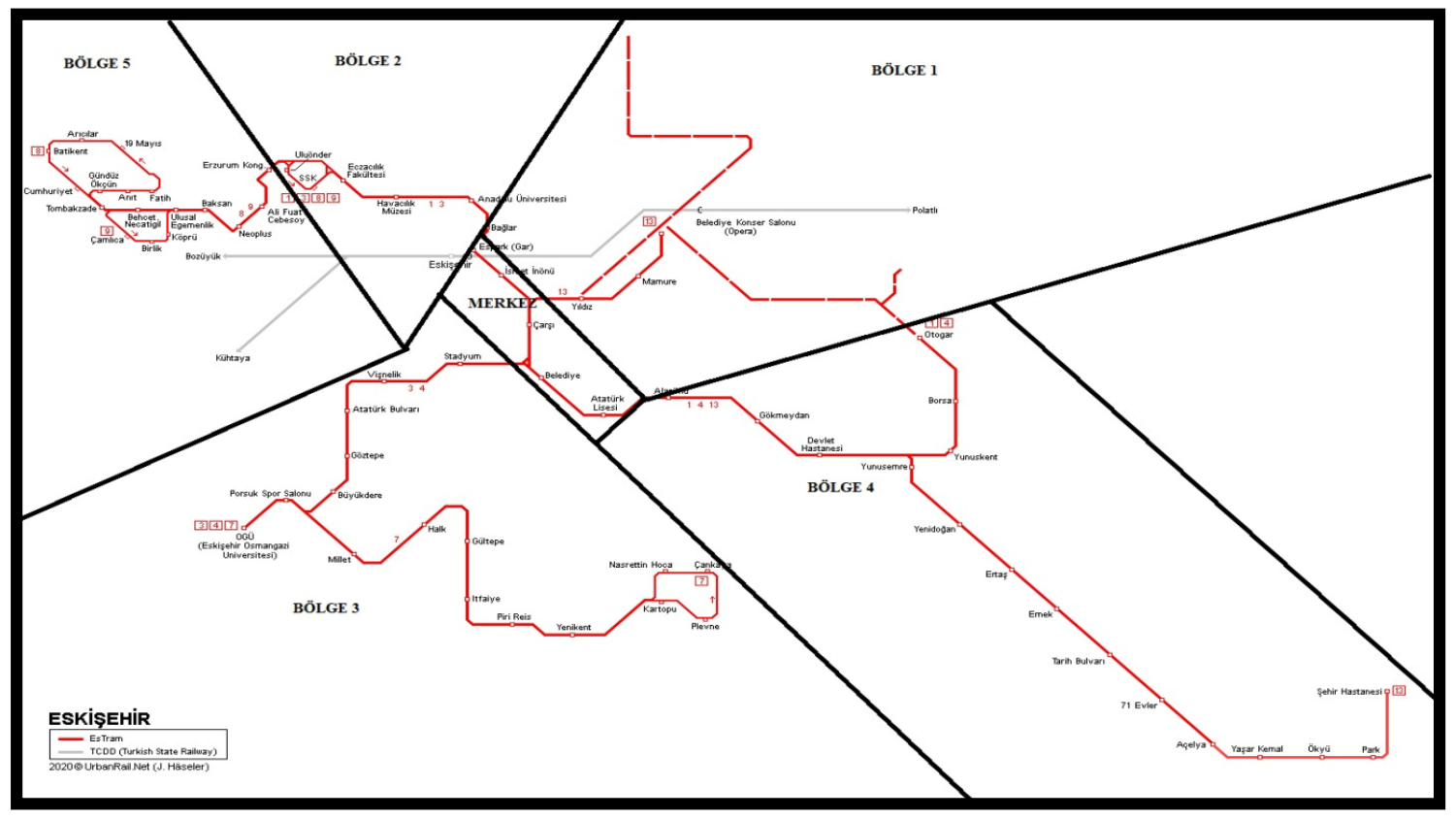

\section{1. Şekil. Eskişehir Tramvay Duraklarının Bölgelere Ayırma Haritası}

Kaynak: Eskişehir Tramvay'ın verilerinden derlenmiştir.

Eskişehir Tramvay'ın yolcu analizi yapıldığında merkezde yoğunlaşan, şehir merkezi dışında bazı hatlarda günün belirli saatlerinde tek yönlü yoğunluk yaşanan ve bazı hatlarında ise hiç yoğunluğun olmadığı tespit edilmiştir. Tramvay trafiğinin şehir merkezi dışına teşvik edilmesi; bölge tarife yardımıyla ile sağlanabilir. Eskişehir Tramvay'ın hatlarının bölgelere ayrılması; "durak yolcu sayıları" ve "ilk biniş bazında elde edilen durak maliyetleri/gelirleri (işletme gelirlerinin maliyetlerine eşit olduğu varsayılmaktadır)" dikkate alınarak gerçekleştirilmiştir. Böylece Eskişehir Tramvay'ın sosyal başabaş noktasında elde ettiği gelirlerde bir azalma olmaması hedeflenmiştir.

2. Şekil'de Ekim 2019 Eskişehir Tramvay yolcu sayı ve gelirleri ile Ekim 2020 benzetimi ile oluşan yolcu sayı ve gelirleri gösterilmektedir. 


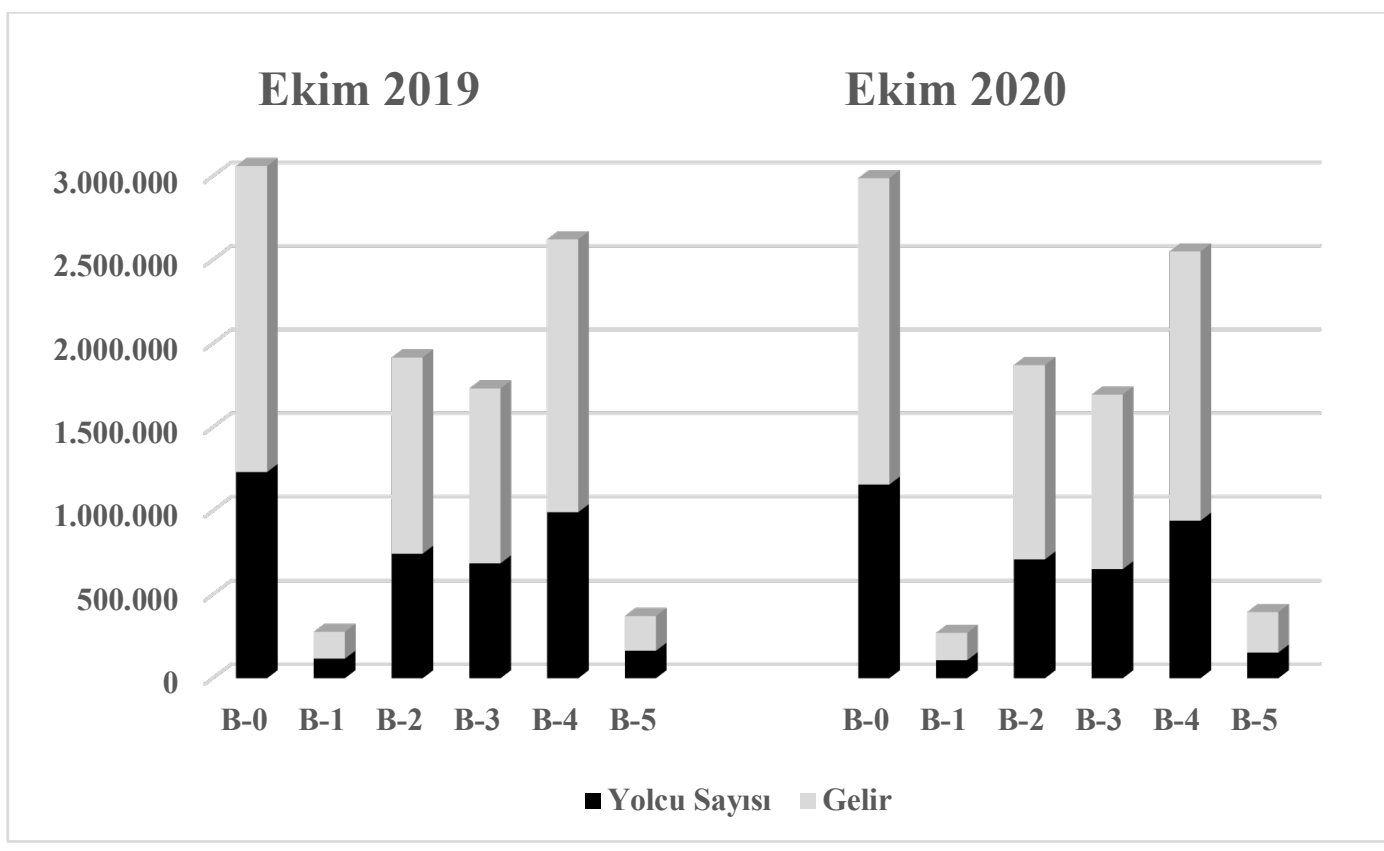

\section{2. Şekil. Eskişehir Tramvay'ın Ekim 2019 ve Ekim 2020 (Tahmini) Dönemine Ait Bölgesel Yolcu Sayısı ve Gelirleri}

Eskişehir tramvay sisteminde yolcu sayısı verisi, yolcunun biniş sırasında turnikeden geçip bilet okutması ile oluşmaktadır. Yolculuk tamamlandığında ise turnike geçişlerine ilişkin bir kayıt alınmamaktadır ve bu nedenle yolcuların durak bazında seyahati hakkında veri elde edilememektedir. Bölgesel tarifenin uygulanabilmesi için, yolcuların ya ilk biniş ve iniş duraklarına ilişkin kayıt alınması ya da sadece ilk biniş durağını tespit ettikten sonra her bölge girişinde aktarma yoluyla bölge geçiş bilgisinin oluşturulması gerekmektedir. Bu sayede hem yolcuların kaç bölgede yolculuk yaptıklarına ilişkin veriler hem de bu yolculuklardan elde edilen gelirler elde edilebilecektir. Bölgesel tarife için gerekli yolcu seyahat hikayesinin olmaması nedeniyle olasılıklar üzerinden veriler oluşturulmaktadır ve bu durum Tablo 3 'te verilmektedir.

Tablo 3. Yolcuların Tramvayda Bölge Kullanılabilirlik Olasılıkları

\begin{tabular}{|c|c|c|c|c|c|c|c|c|}
\hline \multirow[b]{2}{*}{ 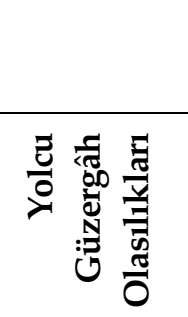 } & \multicolumn{4}{|c|}{$\begin{array}{l}\text { BÖLGE 0'dan binen yolcunun } \\
\text { seyahati }\end{array}$} & \multicolumn{4}{|c|}{ BÖLGE 1'den binen yolcunun seyahati } \\
\hline & 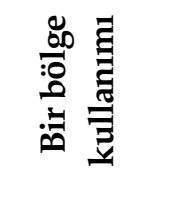 & 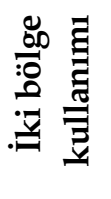 & 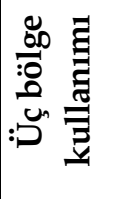 & 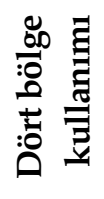 & 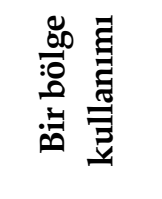 & 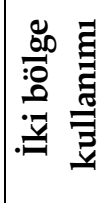 & 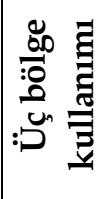 & 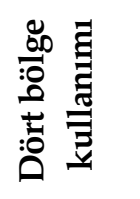 \\
\hline 1. Olasılık & BÖLGE 0 & -- & -- & -- & BÖLGE 1 & -- & -- & -- \\
\hline 2. Olasilık & BÖLGE 0 & 2 & -- & -- & BÖLGE 1 & 0 & - & -- \\
\hline 3. Olasılık & BÖLGE 0 & 2 & 5 & -- & BÖLGE 1 & 0 & 4 & -- \\
\hline 4. Olasılık & BÖLGE 0 & 1 & -- & -- & BÖLGE 1 & 0 & 3 & -- \\
\hline 5. Olasılık & BÖLGE 0 & 3 & -- & -- & BÖLGE 1 & 0 & 2 & -- \\
\hline 6. Olasılık & BÖLGE 0 & 4 & -- & -- & BÖLGE 1 & 0 & 2 & 5 \\
\hline
\end{tabular}




\begin{tabular}{|c|c|c|c|c|c|c|c|c|}
\hline \multirow[b]{2}{*}{ 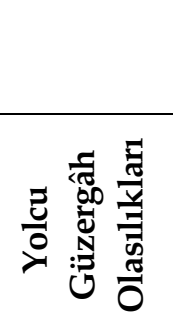 } & \multicolumn{4}{|c|}{$\begin{array}{l}\text { BÖLGE 2'den binen yolcunun } \\
\text { seyahati }\end{array}$} & \multicolumn{4}{|c|}{ BÖLGE 3'ten binen yolcunun seyahati } \\
\hline & 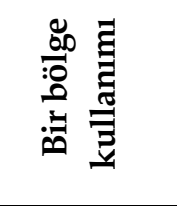 & 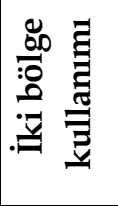 & 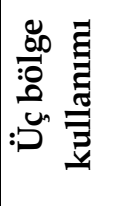 & 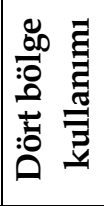 & 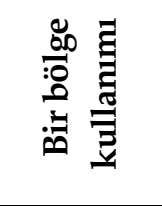 & 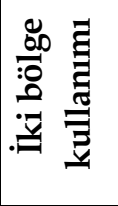 & 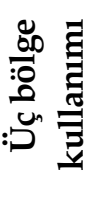 & 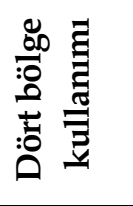 \\
\hline 1. Olasılık & BÖLGE 2 & -- & -- & -- & BÖLGE 3 & -- & -- & -- \\
\hline 2. Olasılık & BÖLGE 2 & 0 & - & -- & BÖLGE 3 & 0 & - & -- \\
\hline 3. Olasılık & BÖLGE 2 & 0 & 1 & -- & BÖLGE 3 & 0 & 4 & -- \\
\hline 4. Olasılık & BÖLGE 2 & 0 & 3 & -- & BÖLGE 3 & 0 & 1 & -- \\
\hline 5. Olasılık & BÖLGE 2 & 0 & 4 & -- & BÖLGE 3 & 0 & 2 & -- \\
\hline 6. Olasılık & BÖLGE 2 & 5 & -- & -- & BÖLGE 3 & 5 & 2 & 5 \\
\hline
\end{tabular}

\begin{tabular}{|c|c|c|c|c|c|c|c|c|}
\hline \multirow[b]{2}{*}{ 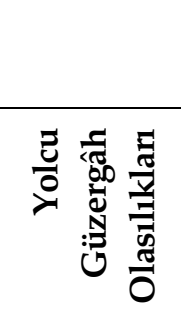 } & \multicolumn{4}{|c|}{$\begin{array}{l}\text { BÖLGE 4'ten binen yolcunun } \\
\text { seyahati }\end{array}$} & \multicolumn{4}{|c|}{ BÖLGE 5 'ten binen yolcunun seyahati } \\
\hline & 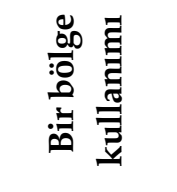 & 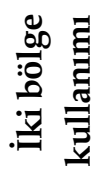 & 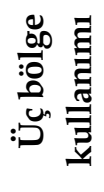 & 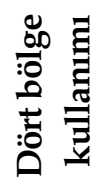 & 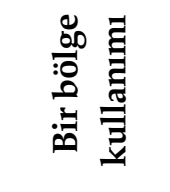 & 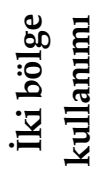 & 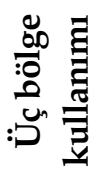 & 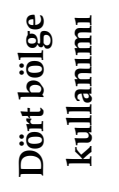 \\
\hline 1. Olasılık & BÖLGE 4 & -- & -- & -- & BÖLGE 5 & -- & -- & -- \\
\hline 2. Olasılık & BÖLGE 4 & 0 & -- & -- & BÖLGE 5 & 2 & -- & -- \\
\hline 3. Olasılık & BÖLGE 4 & 0 & 1 & -- & BÖLGE 5 & 2 & 0 & -- \\
\hline 4. Olasılık & BÖLGE 4 & 0 & 3 & -- & BÖLGE 5 & 2 & 0 & 1 \\
\hline 5. Olasılık & BÖLGE 4 & 0 & 2 & -- & BÖLGE 5 & 2 & 0 & 3 \\
\hline 6. Olasılık & BÖLGE 4 & 0 & 2 & 5 & BÖLGE 5 & 2 & 0 & 4 \\
\hline
\end{tabular}

Tablo 3'ten yararlanarak yolcuların bölgesel tramvay kullanımının dağılımı tahmini olarak hesaplanabilir. Bu hesaplama sonucunda; yolcuların sadece bir bölgeyi kullanma olasıllğı / 36) \%16,667;iki bölgeyi kullanma olasılı̆̆ (10 / 36) \%27,778; üç bölgeyi kullanma olasılı̆̆ (14 / 36) $\% 38,333$ ve dört bölgeyi kullanma olasılığ ise $(6 / 36) \% 16,667$ şeklinde gerçekleşebilmektedir. Bu durum Tablo 4'te verilmektedir.

Tablo 4. Yolcuların Tramvayda Bölge Kullanma Olasılığı Yüzdeleri

\begin{tabular}{|l|c|r|}
\hline Yolcuların Bölgeyi Kullanma Olasılığı & Sıklık & \% Dağılımı \\
\hline Yolcunun BİR BÖLGE'yi kullanma olasılığı & 6 adet & $\mathbf{\% 1 6 , 6 7}$ \\
\hline Yolcunun İKİ BÖLGE'yi birlikte kullanma olasılığı & 10 adet & $\mathbf{\% 2 7 , 7 8}$ \\
\hline Yolcunun ÜÇ BÖLGE'yi birlikte kullanma olasılığı & 14 adet & $\mathbf{\% 3 8 , 8 8}$ \\
\hline Yolcunun DÖRT BÖLGE'yi birlikte kullanma olasılığı & 6 adet & $\mathbf{\% 1 6 , 6 7}$ \\
\hline TOPLAM KULLANIM DAĞILIMI & $\mathbf{3 6}$ adet & $\mathbf{\% 1 0 0 , 0 0}$ \\
\hline
\end{tabular}


Buna göre bir yolcu tramvay yolculuğunu en fazla dört bölgeyi kullandığı görülmektedir. Örneğin Emek durağından (Bölge 4) binen bir yolcunun ineceği durak, kendi bölgesi dahil olmak üzere altı bölgeden birisi olabilir. Emek'ten (Bölge 4) binen bir yolcunun Bölge 4 sinırları içinde olan bir durakta inmesi durumunda 1. Olasılık gerçekleşir ve yolcu sadece bir bölgede yolculuk yapmış olacaktır. Emek'ten (Bölge 4) Atatürk Lisesi'ne (Bölge 0) gitmek isteyen bir yolcu iki bölgede yolculuk yapacaktır (2. Olasılık: Bölge 4-0). Emek'ten (Bölge 4) binip Anadolu Üniversitesi'nde (Bölge 2) inmek isteyen bir yolcu ise üç bölgede yolculuk yapmış olacaktır (3. Olasılık: Bölge 4-0-2). Eğer yolcu Emek'ten (Bölge 4) binip Batıkent'te (Bölge 5) inmek isterse, bu durumda dört bölgede yolculuk yapmış olacaktır (4. Olasılık: Bölge 4-0-2-5). Ayrıca, BÖLGE 0 (Merkez) ve BÖLGE 2'de yolcuların 4 bölge kullanımı olamayacağı varsayımına dayanarak buraya dağıtılan yolcuların orantısal olarak diğer bölgelere dağılımı gerçekleştirilmiştir.

COVID-19 kapsamında bölgesel tarife iki temel esas üzerine kurgulanmaktadır. Bunlardan ilki, tramvayda yolculuk yapanların ihtiyaç dışı gezintilerini önlemektir. Böylece COVID-19 salgınının yayılmasına bir önlem alınmaya çalışılmaktadır. İkincisi ise Eskişehir Tramvay'ın mevcut sabit tarife ile elde etmiş olduğu gelir zaten sosyal başabaş noktasında olması nedeniyle bölgesel tarifeyle de bu gelirin elde edilmesi hedeflenmektedir.

Sabit tarifeden vazgeçilerek, bölgesel tarifeye geçiş ile ortaya çıkacak farklılıklar ise şöyle siralanabilir:

- Bölgelerarası geçişle merkeziyetçi şehir anlayışından şehir merkezi dışına yerleşimi teşvik edilmesi,

- Aktarma ücretinin olmaması,

- Daha adil bir tarifenin oluşturulması,

- Kısa mesafelerde tramvay kullanmak yerine bisiklet veya yaya hareketliliğinin artırılmasidır.

- 65 yaş ve üzeri yolcuların küçük bir bedel karşılığında taşınabilmesi (bu bedel diğer yolcu türlerine yönlendirilerek iptal edilebilir),

Tablo 5. Bilet Türlerine Göre Bölge Kullanımı Esas Alan Tarife Önerisi

\begin{tabular}{|l|c|c|c|c|}
\hline Bölge kullanımları & $\begin{array}{c}\mathbf{1} \text { Bölge } \\
\text { Kullanan }\end{array}$ & $\begin{array}{c}\text { 2 Bölge } \\
\text { Kullanan }\end{array}$ & $\begin{array}{c}\text { 3 Bölge } \\
\text { Kullanan }\end{array}$ & $\begin{array}{c}\text { 4+ Bölge } \\
\text { Kullanan }\end{array}$ \\
\hline Esbilet & 4,20 & 4,20 & 4,20 & 4,20 \\
\hline Eskart İndirimli & 1,10 & 1,00 & 0,80 & 0,30 \\
\hline Eskart Tam & 2,15 & 2,10 & 2,00 & 1,00 \\
\hline 65 yaş ve üzeri & 0,10 & 0,10 & 0,10 & 0,10 \\
\hline Serbestler (Ücretsiz) & 0,00 & 0,00 & 0,00 & 0,00 \\
\hline \multicolumn{1}{|c|}{ Yolcu Yüzdesi } & $\mathbf{\% 1 6 , 6 7}$ & $\mathbf{\% 2 7 , 7 8}$ & $\mathbf{\%} 38,89$ & $\mathbf{\% 1 6 , 6 7}$ \\
\hline
\end{tabular}

Tablo 5'te yolcular hangi sayıda bölgeyi geçerek yolculuk yapıyorlarsa, ilgili bölge kullanımındaki tarifeyi ödemektedir. Örneğin eğer bir öğrenci üç bölgeden geçip okuluna gidiyorsa ödeyeceği ücret $0,80 \mathrm{TL} /$ yolcu olacaktır.

Eskişehir Tramvay tarafından uygulanmakta olan sabit tarife ile tarafımızdan oluşturulan bölgesel tarife Tablo 6 yardımıyla karşılaştırılabilir. Tablo 6' da yolcu türünde yolcu sayısının ve yolcu türünde gelirlerin bölgelere dağıtımında Tablo 2 ve 1 . Şekil'den yararlanılmıştır. Eskişehir 
Tramvay, tramvay hattındaki 61 durak bulunmaktadır. Bu durakların dağılımı şöyledir: Bölge 0'da 5 durak, Bölge 1'de 3 durak, Bölge 2'de 6 durak, Bölge 3'te 17 durak, Bölge 4'te 13 durak ve Bölge 5'te 17 duraktır. Bölgelerin gelirleri; Tablo 5'teki bölgesel tarife önerisindeki değerler ile altı bölge için tayin edilen yolcu sayıları çarpılarak hesaplanmıştır. Tablo 6 ' da sadece Bölge 0 detaylı bir şekilde örneklendirilmiştir. Diğer bölgelerin bilgileri ise toplam değerleri üzerinden verilmiştir.

Tablo 6. Ekim 2020 Benzetim Verilerine Göre Bölgesel Tarifeli Yolcu Sayısı ve Yolcu Gelirleri

\begin{tabular}{|c|c|c|c|c|c|c|}
\hline \multirow{7}{*}{ 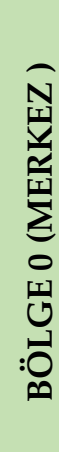 } & Yolcu Sayıları & $\begin{array}{l}1 \text { BÖLGE } \\
\text { Kullanan }\end{array}$ & $\begin{array}{l}2 \text { BÖLGE } \\
\text { Kullanan }\end{array}$ & $\begin{array}{l}3 \text { BÖLGE } \\
\text { Kullanan }\end{array}$ & $\begin{array}{l}\text { 4+ BÖLGE } \\
\text { Kullanan }\end{array}$ & Toplam \\
\hline & ESBİLET & 31.668 & 63.336 & 67.860 & -- & 162.865 \\
\hline & ESKART İNDİRIMLİ & 63.195 & 126.389 & 135.417 & -- & 325.001 \\
\hline & ESKART TAM & 86.996 & 173.991 & 186.419 & -- & 447.406 \\
\hline & 65 YAŞ ÜSTÜ & 22.447 & 44.894 & 48.100 & -- & 115.441 \\
\hline & DİĞER SERBESTLER & 20.820 & 41.639 & 44.614 & -- & 107.073 \\
\hline & Bölge 0 Yolcu Sayısı & 225.125 & 450.250 & 482.410 & -- & 1.157 .785 \\
\hline
\end{tabular}

\begin{tabular}{|c|c|c|c|c|c|c|}
\hline \multirow{7}{*}{ 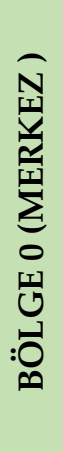 } & Yolcu Gelirleri & $\begin{array}{l}1 \text { BÖLGE } \\
\text { Kullanan }\end{array}$ & $\begin{array}{l}2 \text { BÖLGE } \\
\text { Kullanan }\end{array}$ & $\begin{array}{l}3 \text { BÖLGE } \\
\text { Kullanan }\end{array}$ & $\begin{array}{l}\text { 4+ BÖLGE } \\
\text { Kullanan }\end{array}$ & Toplam \\
\hline & ESBİLET & 133.006 & 266.013 & 285.013 & -- & 684.032 \\
\hline & ESKART İNDİRIMLİ & 69.514 & 126.389 & 108.334 & -- & 304.237 \\
\hline & ESKART TAM & 187.040 & 365.381 & 372.838 & -- & 925.260 \\
\hline & 65 YAŞ ÜSTÜ & 2.245 & 4.489 & 4.810 & -- & 11.544 \\
\hline & DİĞER SERBESTLER & -- & -- & -- & -- & -- \\
\hline & Bölge 0 Gelirleri & 391.806 & 762.273 & 770.995 & 0 & 1.925 .073 \\
\hline
\end{tabular}

\begin{tabular}{|c|l|r|r|r|r|r|}
\hline \multirow{2}{*}{$\begin{array}{c}\text { Bölge } \\
1\end{array}$} & Yolcu Sayısı Toplamı & 17.989 & \multicolumn{1}{|c|}{29.981} & \multicolumn{1}{c|}{41.973} & \multicolumn{1}{c|}{17.989} & \multicolumn{1}{c|}{107.932} \\
\cline { 2 - 8 } & Gelirleri Toplamı & 29.231 & 47.380 & 62.584 & 17.488 & 156.683 \\
\hline
\end{tabular}

\begin{tabular}{|c|l|r|r|r|r|c|}
\hline \multirow{2}{*}{$\begin{array}{c}\text { Bölge } \\
2\end{array}$} & Yolcu Sayısı Toplamı & 138.127 & 236.788 & \multicolumn{1}{|c|}{335.450} & 0 & \multicolumn{1}{c|}{710.365} \\
\cline { 2 - 8 } & Gelirleri Toplamı & 246.553 & 409.682 & 543.603 & 0 & 1.199 .837 \\
\hline
\end{tabular}

\begin{tabular}{|c|l|r|r|r|r|r|}
\hline \multirow{2}{*}{$\begin{array}{c}\text { Bölge } \\
3\end{array}$} & Yolcu Sayısı Toplamı & 108.713 & 181.188 & \multicolumn{1}{|c|}{253.663} & \multicolumn{1}{c|}{108.713} & \multicolumn{1}{c|}{652.277} \\
\cline { 2 - 8 } & Gelirleri Toplamı & 183.412 & 295.148 & 383.699 & 103.426 & 965.685 \\
\hline
\end{tabular}

\begin{tabular}{|c|l|r|r|r|r|c|}
\hline Bölge & Yolcu Sayısı Toplamı & 156.960 & \multicolumn{1}{|c|}{261.599} & \multicolumn{1}{|c|}{366.239} & \multicolumn{1}{c|}{156.960} & \multicolumn{1}{c|}{941.758} \\
\cline { 2 - 8 } 4 & Gelirleri Toplamı & 306.602 & 498.961 & 664.826 & 197.909 & 1.668 .299 \\
\hline
\end{tabular}

\begin{tabular}{|l|l|r|r|r|r|r|}
\hline \multirow{2}{*}{ Bölge 5 } & Yolcu Sayısı Toplamı & 25.581 & 42.634 & 59.688 & \multicolumn{1}{c|}{25.581} & \multicolumn{1}{c|}{153.483} \\
\cline { 2 - 7 } & Gelirleri Toplamı & 42.767 & 69.211 & 91.106 & 23.713 & 226.796 \\
\hline
\end{tabular}

\begin{tabular}{|l|l|l|l|r|r|}
\hline Ekim 2020 Yolcu Sayısı Toplamı & \multicolumn{1}{|c|}{672.493} & 1.202 .441 & 1.539 .425 & \multicolumn{1}{c|}{309.242} & \multicolumn{1}{c|}{3.723 .600} \\
\hline Ekim 2020 Gelirleri Toplamı & 1.200 .371 & 2.082 .654 & 2.516 .813 & 342.536 & 6.142 .374 \\
\hline
\end{tabular}

Eskişehir Tramvay'ın Ekim 2019 yolcu verilerinden yararlanarak yapılan benzetim ile Ekim 2020 yılı verileri tahmin edilmiştir. Ekim 2019 verilerine göre, 3.723 .600 yolcudan aktarım bedelleri 
dahil 6.142.637 TL gelir elde edilmiştir. Benzetim ile oluşturulan Ekim 2020 tahminleri ise şöyle oluşmuştur: Yolcu tiplerinde değişiklik yapılmadan aynı yolcuların tarafımızdan önerilen bölgesel tarifenin kullanılması durumunda 3.723 .600 yolcudan aktarım bedeli alınmadan 6.142.374 TL gelir edileceği öngörülmüştür. Bu durumda Ekim 2019 ile Ekim 2020 arasında neredeyse gelir/maliyet fark1 yoktur (fark1-263 TL'dir). Tablo 5'teki bölgesel tarifenin oluşturulma temel ilkesi; COVID-19 dönemindeki kısa mesafeli yolculuklardan caydırma ve uzun mesafeli yolculukları ise teşvik etmektir. Uzun dönemde bu amaca ulaşılması durumunda 1. ve 2. bölge kullanımında yolculuk yapanların sayısı azalırken, 3. ve 4. bölge kullanımının artması hedeflenmektedir. Bu hedefe, vatandaşlarının büyükşehir merkezindeki ihtiyaçlarının tümünün alt belediyeler tarafından karşılanması durumunda yolculuklar kısalacağı için de ulaşılabilir. Böyle bir durumda tramvay hatlardaki sefer sayıları, sefer saatleri, yolculuk türlerine göre yolculuk sayıları değişiklik gösterebilir. Ancak bölgesel tarife esnek yapısı sayesinde tarifede güncelleme yapılabilir.

\section{SONUÇ VE ÖNERILLER}

Eskişehir büyükşehir statüsünde olmasına rağmen merkeziyetçi anlayışını hâlâ korumaktadır. Bankalar, büyük marketler, resmî kurumlar şehrin merkezinde ya da merkeze yakın bir şekilde konumlanmaktadır. Bu nedenle Eskişehir büyükşehir olmasına rağmen, ihtiyaçların karşılanması anlamında butik bir şehrin özelliklerini taşımaktadır. Bu nedenle Eskişehir'de yaşayanlar şehir merkezinde ikamet etmeseler bile şehir merkezine gelme ihtiyacı duymaktadır. Eskişehir tramvay sistemi de şehir merkezinde kesişen iki ana hat üzerine kurulmuştur. Bu nedenle merkeze gelmek veya bir noktadan diğer noktaya ulaşmak isteyen bir kişi, her hâlükârda şehir merkezini ziyaret etmek durumunda kalmaktadır. Bu durum ise şehir merkezindeki tramvay hatlarının çok yoğun olmasına neden olmaktadır.

Türkiye'nin 11 Mart 2020 tarihi itibariyle COVID-19 salgın hastalık ile tanışmasıyla birlikte, yeni sosyal hayata uyum sağlaması bir gereklilik haline gelmiştir. Hükümet COVID-19 atakları süresince alışveriş, tatil, eğitim ve ulaşım gibi birçok vazgeçilmeze yeni kurallar getirmiştir. İl Umumi Hıfzıssıhha Kurul Kararları ile toplu taşımacılıkla ilgili olarak temizliği ön plana çıkartmış ve yolculuk yapanların sayısını da araç kapasitesinin yarısına indirilmiştir. Böyle bir durumda toplu taşımacılığın şehir merkezinde yoğunlaşan Eskişehir' in yeni önlemleri hayata geçirmesi gerekmiştir. 11 Mart - 1 Haziran 2020 döneminde 65 yaş ve üzeri ile 18 yaş ve altı vatandaşların sokağa çıkma yasağı, hafta sonları sokağa çıkma kısıtlaması, okullarda örgün eğitime ara verilmesi, ülkelerarası ve şehirlerarası seyahat yasağının getirilmesi, resmî kurumlarda çalı̧̧anlara esnek çalışma olanağı yaratılması, kademeli çalışma saatlerinin düzenlemesi, iletişim araçlarıyla salgın hastalık farkındalığının artırılması gibi alınan birçok önlem toplu taşımayı da doğrudan etkilemektedir. Bununla birlikte yaz döneminde tatil veya memlekete gidilmesi, yurtdışı seyahat kısıtları nedeniyle yurtdışında yaşayan Türklerin Eskişehir'i ziyaretinde geçmiş yıllara göre azalma yaşanması ve üniversite öğrencilerinin memleketlerinde olması gibi nedenlerle şehir nüfusu kış dönemine göre daha az olması beklenmektedir. Bu durum toplu taşımaya olan talebi azaltacağı için söz konusu sorunlar daha az hissedilebilir.

Bilim insanları sonbaharda bağışıklık sisteminin zayıflamasıyla birlikte salgın hastalıkta ikinci bir dalga beklentisi içindedir. Aşı çalışmaları birçok ülkede tüm hızıyla devam etmesine rağmen Dünya Sağlık Örgütü'nün öngörüsüne göre, aşının 2021 yılı başlarında ancak uygulanabileceği tahmin edilmektedir. Yüz yüze eğitimin tekrar başlayıp başlamayacağı ise kesin değildir. Son yıllarda Eskişehir yurtiçi turizmi de artış göstermiş ve özellikle sonbaharda turist potansiyeli yüksek bir destinasyona sahip olmuştur. Bu koşullar altında normalleşme sürecinde toplu taşıma araçlarının ancak \%50 kapasite ile çalışması durumunda Eskişehir Tramvay'ın ulaşım ihtiyacını karşılayabilmesi için özellikle belirli saat aralıklarında sefer sayısını iki katına çıkarması 
gerekecektir. Toplumun belirli bir kesimi COVID-19'a karşı aşırı duyarlı davranmaktadır. Bu kesimin ulaşımlarını kendi araçlarıyla yapması ya da evlerinde çalışmayı yeğlemesi beklenmektedir. Çalışmada bu kesimin toplum içindeki payının $\% 5$ olabileceği varsayılmıştır. Bu koşullar altında Eskişehir şehir içi trafiğinin büyük bir sorunlarla karşılaşılacağı tahmin edilmektedir.

Çalışmada, şehir içi raylı toplu taşıma sorunun aşılmasında bölgesel tarife önerisinde bulunulmaktadır. Bölgesel tarifenin hazırlanmasında ilk aşama bölgelerin tanımlanmasıdır. Bölgeler; şehir merkezi (Bölge 0) ve şehir merkezi dışı (Bölge 1-2-3-4-5) olmak üzere altı bölgede tanımlanmaktadır. Bölgesel tarifede temel amaç kısa yolculuklardan ziyade uzun yolculukların özendirilmesidir. Günübirlik turistlerin özellikle salgın döneminde azaltılması amacıyla tarifesi (Esbilet) olabildiğince yüksek bir bedel üzerinden belirlenmiştir. Ayrıca 65 yaş ve üzeri kullanıcıların tramvay kullanım alışkanlıklarının yıllar itibariyle değiştiği gözlemlenmektedir. 2010 yılında 65 yaş ve üzerinin ücretsiz binişine ilişkin yasal düzenlemeden önce toplam yolculuğun \%3'ü bu gruba aitken, günümüzde bu oran \%13'e ulaştığı görülmektedir. COVID-19 salgınında 65 yaş ve üzeri yolcuların korunması amacıyla bu kesimden sembolikte olsa bir ücret $(0,10$ TL gibi) talep edilmesi, yolcu sayısında önemli bir azalmaya neden olacağ 1 düşünülmektedir. Ayrıca önerilen bölgesel tarife incelendiğinde, bir bölge kullanan yolcunun ulaşım maliyeti ile dört ve daha fazla bölge kullanan yolcunun katlanacağı maliyet arasında önemli bir farklılık olduğu görülecektir. Böylece şehir merkezinden uzakta ikamet etme özendirilebilir ve ilçe belediyeleri ön plana çıkartılarak şehir merkezindeki tüm hizmetlerin verilmesi sağlanabilir.

Bu çalışmada, COVID-19 salgın hastalığının sonbaharda devam edeceği varsayımıyla, tramvay sisteminin Ekim 2020'de yaşayabileceği ortam ve karşılaşılabilecek gelir-maliyet durumu Ekim 2019 verileri göz önünde bulundurularak benzetim yoluyla öngörülmeye çalışılmıştır. Toplu taşıma işletmelerinin temel amacı, kâr sağlamak veya kârını artırmak değildir. Temel amaç, gelirlerini başabaş noktasına elde edebilecek bir tarife belirleyebilmektir.

Sonuç olarak; COVID-19 döneminde alınan önlemlerle birlikte toplu taşıma işletmelerinin gelirleri düşerken, maliyetleri yükselecektir. Bu durum sabit tarifede fiyat artışına neden olacaktır. Bu nedenle, toplu taşıma işletmelerinin böyle bir dönemde başabaş noktasının altında bir gelir elde etmeyi göze alarak, sosyal başabaş noktasında maliyetleri karşılama yoluna gitmelidir. Bu kapsamda sabit tarifeden vazgeçilerek daha dinamik bir yapıya sahip olan bölgesel tarifeye geçilmelidir. Bölgesel tarife dinamik yapısıyla; bugün COVID-19 mücadelesine katk1 sağlarken, gelecekte şehrin yerleşim planlanması, ulaşım yatırım kararları ve yolculuk seyir alışkanlıklarının değiştirilmesi gibi kararlarda etkin rol oynayacağı düşünülmektedir.

$\mathrm{Bu}$ çalışma, sadece bir toplu taşıma işletmesinden alınan bir aylık veri ile sınırlı kalmıştır. Gelecekte yapılacak çalışmalarda, daha büyük bir veri setiyle Türkiye'deki tüm toplu taşıma işletmelerini kapsayan ve dünya örnekleriyle karşılaştırılabilen çalışmalar yapılabilir.

\section{KAYNAKÇA}

Alkan, A. Levent (02.09.2020). Salgııın Külleri Altında Kalan İkinci Çeyrek Büyümesi https://www.dunya.com/kose-yazisi/salginin-kulleri-altinda-kalan-ikinci-ceyrekbuyumesi/480116, (Erişim Tarihi: 03.09.2020).

Allaire, J., Meteyer-Zeldine F., Gouin T. ve Bouhmad, K. (2014). Who Pays What for Urban Transport?: Handbook of Good Practices. CODATU [https://ec.europa.eu/ transport/sites/transport/files/cycling-guidance/who_pays_what_for_urban_transport__handbook-of-good-practices.pdf, (Erişim Tarihi: 14.04.2020). 
Benk, S. ve Akdemir, T. (2010). Toplu Taşıma Hizmetlerinde Fiyatlama Stratejileri: Teorik Bir Değerlendirme. Ekonomi Bilimleri Dergisi. 2 (1), 131-138.

Çakır Yıldız, N. Uluslararası Pazarlama. İstanbul Üniversitesi Açık ve Uzaktan Eğitim Fakültesi Dış Ticaret Önlisans Programı, 440. [Online] http://auzefkitap.istanbul.edu.tr/ kitap/disticaret_ue/uluslararasipazarlama.pdf, (Erişim Tarihi: 05.09.2020)

Çörekçioğlu, S. ve Sezen, B. (2011).Üretim Etkinliğinin Arttırılmasında Simülasyon Yaklaşımı Ve Bir Üretim Atölyesinde Uygulama. Kafkas Üniversitesi İktisadi ve İdari Bilimler Fakültesi Dergisi (KAÜİ̈BFD) 1 (2), 53-75.

Demir, K. ve Çabuk, S. (2010). Türkiye'de Metropoliten Kentlerin Nüfus Gelişimi. Sosyal Bilimler Enstitüsü Dergisi (28), 193-215.

Duru, S. (2019). Corona Virus Hastalığı 2019 (Covid 19) ve Akciğer: Göğüs Hastalıkları Uzmanlarının Bilmesi Gerekenler. Ak, G (Ed.) Eurasian Journal of Pulmonology içinde (ss. 125-131).

EEA-European Environment Agency (2001). Indicators Tracking Transport and Environment Integration in the European Union, European Environment Agency, Copenhagen. [Online] https://www.eea.europa.eu/publications/term2001-sum, (Erişim Tarihi: 09.04.2020).

Ekergil, V., \& Ersoy, N. F. (2016). B2B/Endüstriyel Pazarlar İçin Anahtar Müşteri Yönetimine İlişkin Müşteri Yaşam Boyu Değerinin Hesaplanmasında Muhasebe ve Pazarlamanın Rolü. Business \& Economics Research Journal, 7 (4).

Keskin, Uğur (Temmuz 2020). Ulaşım Sistemlerinde Etmen Tabanlı Simülasyon Geliştirilmesi Ve Bir Lojistik Firmasında Vaka Çalışması. İstanbul Medeniyet Üniversitesi Yayımlanmamış Yüksek Lisans Tezi: 79 [Online] http://hdl.handle.net/123456789/420, (Erişim Tarihi: 15.09.2020).

Koyuncu, H. (26.04.2020). “Koronavirüs (COVID-19) Salgını Ne Zaman Bitecek?” Euronews. [Online] https://tr.euronews.com/2020/04/26/koronavirus-COVID-19-salgini-ne-zamanbitecek, (Erişim Tarihi: 18.05.2020).

Litman, T.A. (2009). Transportation Cost and Benefit Analysis Techniques, Estimates and Implications (2nd Edition). [Online] https://www.vtpi.org/tca/tca00.pdf, (Erişim Tarihi: 20.04.2020).

Özçelik, S. (2011). Şehir İçi Ulaşım ve Otomotiv Sektörü. TAYSAD Dergi, 13 (60), 4.

Öztürk, R., Kınıklı, S. ve Cesur, S. (Haziran 2015). Toplum Kökenli Pnömonilerde Tanı ve Tedavi. Türk Klinik ve Laboratuvar Dergisi, 6 (2), 63-72.

Öztürk, Z. ve Öztürk, T. (2010). İstanbul Kara Ulaşımında Alan Kullanımı Ekolojik Faktörünün Belirlenmesi. IMO Teknik Dergi, 21 (101), 4979-4985.

T.C. Sağlık Bakanlığı Halk Sağlı̆̆ı Genel Müdürlüğü (2017). Bulaşıcı Hastalıklar İle Mücadele Rehberi, Genelge 2018-22 [Online] https://hsgm.saglik.gov.tr/depo/mevzuat/genelge/ Bulasici_Hastaliklar_ile_Mucadele_Rehberi_Ustyazi.pdf, (Erişim Tarihi: 17.05.2020).

TUIK, (31.08.2020). Sayı: 33605: Dönemsel Gayrisafi Yurt İçi Hasıla, II. Çeyrek: Nisan - Haziran, 2020 [Online] http://www.tuik.gov.tr/PreHaberBultenleri.do?id=33605, (Erişim Tarihi: 03.09.2020).

Zorlu, Fikret (2008). Planlamada Belirsizlik Sorunu: Ulaşım Planlamasında Yolculuk Talebi, Magaron YTÜ Mimarlık Fakültesi E-Dergisi, 3 (1), 31. 
https://www.ardesentso.org.tr/Upload/Dosyalar/dosya-pdf/normallesmeplani-r3-cf4a553c-59154015-95a9-163740e074f6.pdf, (Erişim Tarihi: 17.09.2020).

https://www.icisleri.gov.tr/koronavirus-salgini-ile-mucadele-kapsaminda-marketlerle-ilgili-ekgenelge, (Erişim Tarihi: 17.09.2020).

http://www.ozelogretim.hacettepe.edu.tr/grup3/benzetim.php, (Erişim Tarihi: 11.06.2020).

http://www2.estram.com.tr/Cntnt/69 (Erişim Tarihi: 03.05.2020). 